\title{
The Taihe Literary Style of the Northern Wei Dynasty under the Influence of Confucianism
}

\author{
Chenchen Gao \\ School of Liberal Arts \\ Northwest Minzu University \\ Lanzhou, China 730000
}

\begin{abstract}
Taihe period was an important historical stage in the Northern Wei Dynasty. Before the Taihe Period, the Northern Wei regime only used the Confucianism inherited by the Han scholars as a political means, which limited the development of the literature of the Northern Wei Dynasty. After the Taihe Period, the integration of the North and the South strengthened, and the regional Confucian culture was further infiltrated into the literary creation. During the Northern Wei Dynasty, the Hanization was deepened further. The author will analyze the literatures of the Northern Wei Dynasty under the influence of regional culture and Confucianism in the Taihe Period, and the influences of northern minorities' culture with the Northern Wei Dynasty as the representative of the northern minority culture.
\end{abstract}

Keywords-regional culture; Confucianism; Taihe literary style; prose; poetry

\section{INTRODUCTION}

The Northern Wei Dynasty was an important period for the development of northern culture in Chinese history. The development of literature and culture at this stage had a profound influence on the Sui and Tang Dynasties, and reflected the blend of the north and the south cultures, and the positive influence of the advanced culture of the Central Plains on the culture of the northern minorities. The traditional culture represented by Confucianism was gradually accepted by the northern minority regime and played a role in reforming the society and changing the style of literature. In the ideological system of Confucianism, the relationship between the scholars and the political relations, and the discussion of the social ethics are many, and the influence is also great. These ways of thinking and the rules of conduct are deeply penetrated into the literary concepts of Confucianism, which affect the development of the literature of the Northern Wei Dynasty from all aspects. The paper is designed to analyze the positive significance of Confucian culture to the Northern Wei literature from prose and poetry in literary creation in the Taihe Period. In the Northern Wei Dynasty, after the reform of Emperor Xiaowen, the blend of the north and the south cultures was particularly obvious at this stage.

\section{THE BACKGROUND OF THE TAIHE LITERARY STYLE IN THE NORTHERN WEI DYNASTY}

Emperor Xiaowen of the Northern Wei Dynasty ascended the throne in the first year of Yanxing (471), and came to power in the fifteenth year of Taihe (491), and died in the twenty-third year (499). During the reign of Emperor Xiaowen, he paid great attention to education reform and absorbed the excellent cultural tradition of the Han nationality. He not only emphasized the cultural and literary education of the younger children of Xianbei, but also widely used the scholars of Han Confucianism and literature. He began to search for "the remains of the world" ${ }^{1}$ and devoted his great enthusiasm to literary creation. Even "the articles he wrote were many and long". ${ }^{2} \mathrm{He}$ often organized the literary activities of the collective, and talked with the officials about the poems and the gains and losses. He compiled poems and prose of himself and officials into anthology. Emperor Xiaowen was influenced by the culture of the Central Plains and studied the Confucian classics since childhood. Under the reins of famous Emperor Wudi of Han Dynasty and Emperor Wendi of Wei Dynasty, they attached great importance to the literature. During their reign, the literary thought of the Northern Wei Dynasty showed some new features on the basis of the early inheritance. First of all, Emperor Xiaowen attached importance to the role of literature in political education. On the other hand, he also showed the tendency to entertain himself with literature. Secondly, the process of communication between the North and the South has begun, which is of great significance in the literary thought history of the Northern Dynasties, and the later literary thoughts of the Northern Dynasties were carried out in this background. Therefore, the Taihe period in which Emperor Xiaowen was in power was actually a transition and a turning point in the development of the Northern Dynasty's literary thoughts.

The development of literature in the Northern Wei Dynasty is a reflection of the cultural differences between the north and the south and the process of Hanization. In the literature of the Northern Dynasty, the literature development of the Northern Wei can become a representative of the region, which is

(Northern Qi) Wei Shou, Wui Shu·Emperor Gaozu, China Book Bureau, 1974, Page 161.

(Northern Qi) Wei Shou, Wui Shu • Biography of Han Qilin (attached Biography of Han Xianzong), China Book Bureau, 1974, Page 1331. 
different from the southern culture represented by the Southern Dynasty. First, the literature of the Southern Dynasties paid much attention to the manifestation of psychological emotion, and the articles were beautiful in words. The literature development of northern dynasties taking the Northern Wei Dynasty as representative was still consistent with the process of Hanization. It paid attention to the practical view of literature, prose and poetry, and took the priority. The Hanization of the Northern Wei Dynasty and the development of Confucianism went through such a stage: In the early period of the founding of the Northern Wei Dynasty, the change of society was a state affair, and the government was increasingly aware of the differences between the culture of the nation and the Central Plains and the southern regime, and began to absorb some of the beneficial elements in the culture and make the national political system and customs Confucian. After the reforms of Hanization of Emperor Xianwen, Emperor Xiao and Emperor Xuanwu, the ideological system of Confucianism gradually soaked into the upper society of the Northern Wei Dynasty, which caused the prosperity of the academic thought and changed the ideological tradition of Xianbei people. The development of Confucianism in the Northern Wei Dynasty began to influence the psychology of a group of scholars from the political level, and influenced the transformation of cultural psychology in the form of the state system, and the spread of Confucianism in the Northern Wei Dynasty was manifested not only in the state system, the rules of etiquette, but also in the educational system. Wei Shu - Taizu Ji recorded Emperor Wudi, "in the third month and second year of Tianxing, gathered scholars to study the classics and increased 3000 students in the official academy" 3 . After moving capital to Luoyang, he also established Guozi, Taixue and Simen academies" 4 . Thus, in the period of Emperor Daowu, the Northern Wei Dynasty had formed the central government system, including Guozi, Taixue and Simen academies, which made the Confucian thought permeate the society of the Northern Wei Dynasty in the form of the mutual promotion between the central and the local.

Accordingly, taking the Taihe period as the time node, the Northern Wei regime first used the Confucianism as a political means to govern the state, and then changed their attitude and gradually it infiltrated into their literary creation, and thus promoted the progress of the literary world and the blend of the north and the south cultures. It can be seen that the literature development of Northern Wei Dynasty is consistent with the integration of north and south cultures and the influence of Confucianism. Therefore, the paper analyzes the influences of Confucianism on the literatures of the Northern Wei Dynasty and the culture of northern minorities with the Northern Wei Dynasty as the representative in the Taihe Period.

(Northern Qi) Wei Shou, Wui Shu • Emperor Taizu, China Book Bureau, 1974, Page 19.

(Northern Qi) Wei Shou, Wui Shu • Rulin Liezhuan, China Book Bureau, 1974, Page 1843.

\section{TAIHE PROSE UNDER THE INFLUENCE OF REGIONAL CULTURE}

Located in the north, the Northern Wei regime was less influenced by the southern metaphysics, and under the influence of the Confucian culture, political literature began to be inclined to the Confucian Viewpoint and pursued to be real and practical. In the Taihe period of the Northern Wei Dynasty, the prose creation was mainly practical writing, which was in accordance with the emphasis on the political affairs and the view of the practice of life. Taihe literature generally inherited the simple style of writing in the early Northern Wei Dynasty. Both poetry and prose reflect the simplicity and elegance. This indicates that Taihe literary tended to plain and elegant in general. Although the literary world was more active than that of the Northern Wei Dynasty in the Taihe Period, there was no great change in literary thought. Compared with the early Northern Wei Dynasty, the thought of emphasizing political education was desalinated. However, the literature still continued the early "simple and classical" style and formed the elegant and simple literary thought. As Sui Shu - Jing Ji Zhi said: "then Emperor Weiwen attached importance to poetry, and did not change original style and still pursued the style of simplicity" ${ }^{5}$.

In the period of Emperor Xiaowen, there were a number of famous ministers and scholars, among which Liu Fang and $\mathrm{Li}$ Biao were famous for understanding Confucian classics. Cui Guang and Xing Luan were distinguished by understanding the literary history. Yuan Xie, Yuan Cheng, Li Chong, Li Biao, $\mathrm{Mu}$ Liang, Wang Su and Gao Lv were famous men of letters who had literary works to remain in the world. On one hand they firmly supported the hanization reform of Emperor Xiaowen, and played an important role in making rites and music and reforming the old customs. So they were famous ministers in the Taihe Period. On the other hand they created literary works and changed the style of literature. Their literary works under the influence of the Taihe literary style and the Confucian culture are also worthy of attention. The following examples of literary works can be used to spy on the cultural connotation of Confucianism in their prose.

\section{A. The Prose Creation of Emperor Xiaowen}

Emperor Xiaowen was the most remarkable monarch in the period of the Northern Wei Dynasty. He was keen on reforming, moving to Luoyang, absorbing the culture of the Central Plains, and reforming the style of writing. It can be said that the formation of the Taihe literary style and the influence of the Confucian culture on the minority nationalities in the north are attributed to the efforts of the monarchy. Emperor Xiaowen followed the tradition of "collecting poems to see the folk customs" by the ancient emperors and inspected the political gains and losses by the folk songs, which manifested both beauty and irony. "Collecting poems to see the folk customs" is a reflection of Emperor Xiaowen on examining the deeds of ancient times, to distinguish right from wrong, and stressing the thought of political education. As the representative of reforming of the Central Plains and stressing

\footnotetext{
Page 903.
} 
"rites and music", Emperor Xiaowen thought that the Northern Wei should have had a great event on literature. He always focused on showing the elegant temperament and interest of literati when making poems with his ministers, reflecting the image of a prominent monarch influenced by the Confucian culture. Through the articles of Emperor Xiaowen, written in the Collection of Three Ancient Dynasties, Qin, Han, Three Kingdoms and Six Dynasties, ${ }^{6}$ we can see his Confucian thoughts. Qiu Yan Zhao and Qiu Zhiyan Jijian Zhao said: "all official encouraged each other to assist the emperor and never slack off. If they had good ideas to benefit the nation and the masses, they would say directly" 7 . It shows that a sage monarch was thirst to seek men of virtue and talents, showing the changes of the political ideology of the Northern Wei Dynasty influenced by the Confucian culture. Advice on Farming and Sericulture, Investigation on Farmers, Worrying Drought, Pray for Raining, Imperial Edict on Exempting Tax, Jun Tian Zhao and Blaming Oneself for Drought wrote: "I was so sad about the disasters. We couldn't forecast the weather and prevent the disasters. It rained a heavy fall rain and resulted in flood. Ordinary people whined and cried. I have mercy on them, so I sent officials to relieve people in the disaster". Imperial Edict on Exempting Tax wrote: "I have sinned, and don't blame others... I need to reflect myself and receive punishment". The words and emotion in Blaming Oneself for Drought were earnest, and thought for the people. Advice on farming and sericulture reflects the traditional people-oriented thought and the Confucian thought of benevolence. Ordering Gao Lv and Da Le to Collect Folk Songs wrote: "we have had the system of rites and music since ancient times. Former emperors used music to coordinate the internal officials and rites to prevent foreign invasion... and compiled them in classics". The Confucian thought is particular about rites and music, which has also been adopted by Emperor Xiaowen. So he ordered his officials to make rites and music and follow the ways of ancient emperors, which greatly reflect the influence of Confucianism on him.

\section{B. The Prose Creation of Other Writers in the Taihe Years}

In the Taihe period of the Northern Wei Dynasty, there were many famous men, such as Diao Yong, Gao Yun, Liang Zuo, Han Xingzong and Gao Lv, which were remembered by the times. They were greatly influenced by Confucianism, and dared to say their opinions directly and loved the country and the people.

According to records of Wei Shu . Diao Yong Biography, "Diao Yong was generous and gentle. He was fond of classics and greatly loved them. He was good at writing poems, prose and essays, and left more than one hundred works" ${ }^{8}$. Collection of Three Ancient Dynasties, Qin, Han, Three Kingdoms and Six Dynasties has collected his works, including Memorial for Promoting Rites and Music, Memorial for

6 (Qing) Yan Kejun, Editor. Articles of Ancient Three Dynasties, Qin, Han, Three Kingdoms and Six Dynasties, China Book Bureau, 1958.

(Qing) Yan Kejun, Editor. Wei Shu Volume 3 in Articles of Ancient Three Dynasties, Qin, Han, Three Kingdoms and Six Dynasties, China Book Bureau, 1958, Page 213.

(Northern Qi) Wei Shou, Wei Shu · Diao Yong Biography, China Book Bureau, 1974, Page 865.
Practicing Filial Piety, Memorial about Bogulv Town, Memorial for Asking for Water Way and Memorial for Hexi Construction, in the 26 chapter of Weiwen. They are all articles about political affairs and represented by utilization, reflecting national and civil affairs and sighing the destiny of a country and the times. They were reflections of classic Confucian thought. Among them, Memorial for Promoting Rites and Music wrote: "I heard that great nations all attached importance to rites and music... Only sages know music and rites are not for themselves, so they play it for the heaven and follow it on the earth. Therefore, they obey the way of the heaven and cater the feeling of man. Emperors made rites and music for their state... in the Wei and Jin Dynasties, the system of rites and music collapsed. I advise My Majesty to follow the emperors, and select men of virtue and talents to amend the rites and music. Thus, teach the officials and the people. In this way, our country could be better. I believe before studying Confucianism our sight is short, so I earnestly advice to amend rites and music in order to improve the government of our country",. He wrote memorial to Emperor Xiaowen to amend rites and music. Borrowing the words of Yue Ji and following the examples of Emperor Yao and Shun, he said to "make rites and music to touch the heaven and educate the people, and it was good". We can see his admires on the system of rites and music. First, he gave an example of ancient emperors who carried out the system of rites and music. $\mathrm{He}$ explained the important relationship between rites and music. Then he analyzed the collapse of rites and music in the Wei and Jin Dynasties. He advised emperor paying attention to the importance of the system of rites and music. At last, he emphasized the achievement of Emperor Xiaowen since his throne. "I believe before studying Confucianism our sight is short, so I earnestly advice to amend rites and music in order to improve the government of our country", which had quoted the classics and was earnest. It profoundly reflects the influence of Confucianism on Diao Yong. Memorial about Bogulv Town, Memorial for Asking for Water Way and Memorial for Hexi Construction were written after his field visit, and he gave advice to the emperor. Memorial for Practicing Filial Piety was also representative work of Confucian thought.

Gao Yun, in the Shenjia years, was Zhongshu Boshi (official post), and later he was served as Shilang to teach imperial sons ${ }^{10}$. From his status, we can see his cultural accomplishment. His works, including Memorial about Astronomy Disaster, Memorial about School Construction, Memorial about Emperor Wencheng Not Changing Folk and Customs, and Jiu Xun, were collected in chapter 28 of Weiwen. In his articles, there are many quotations from Confucian classics. And we can feel his responsibilities on prospering country and governing the state as an official of Northern Wei. They all reflect the influence of Confucianism on his literary works.

Li Chong's Reply Memorial has said all kinds of kindness and expressed his loyalty and gratitude to the emperor. Other

(Qing) Yan Kejun, Editor. Wei Shu Volume 26 in Articles of Ancient Three Dynasties, Qin, Han, Three Kingdoms and Six Dynasties, China Book Bureau, 1958, Page 440.

10 (Northern Qi) Wei Shou, Wui Shu • Biography of Gao Lv, China Book Bureau, 1974, Page 1196. 
writers of Taihe years, such as Li Biao, Liu Fang and Xing Luan, also have essays handed down to the world, and present a literary tendency under the influence of Confucianism. Under the double influence of Taihe literary style and Confucianism, the Taihe literary world in the Northern Wei Dynasty showed an ideological and literary promotion. The articles paid more attention to the analysis of the inner world. It was a backwash to the nervous and constrained literary thought of the previous generation, which helped to promote the development of later literature.

From the above writers' works, we can see that the applied prose of the Northern Wei Dynasty formed a new characteristic in the Taihe Period of Emperor Xiaowen, and was recognized and accepted by the writers and formed the socalled "Taihe literacy style". The general characteristics can be summed up as the following two points:

First, in the language sentence pattern, the prose creation of the Taihe period changes the previous fixed sentence pattern of the four words, and the sentence pattern is flexible and changeable, making the article easier to read. The article also began to pay attention to quotations, increased the connotation of the article, and also reflected the influence of Confucian culture on Taihe's prose creation. The Taihe literary style was accepted and practiced by many writers after the Emperor Xiaowen of the Northern Wei Dynasty. After that, it formed the general style of prose writing in the Northern Wei Dynasty. In the analysis of above works, it is also noted that many prose and poems were wrote by Emperor Xiaowen and his official Xiang He. Emperor Xiaowen ordered his officials to give advice and his officials give suggestions without worry, which is also the reflection of Confucian culture.

Secondly, the prose creation in Taihe period began to have a personalized tendency. The political view of the writers was free from the thinking mode of Cui Hao and Gao Yun and others in the former period. The development of Confucianism made the writer's thought of the Taihe period break through the conservative and retro state in the previous period and presented some personality characteristics. During the Taihe Period, the cultural blend of the North and the South and Confucianism thought expanded further. Writers began to add their own true feelings in the creation of their own applied prose and examine problems and build article with the Confucian thought of benefiting the world. Seen from articles wrote by Cui Guang and Xing Luan and other writers of Taihe period, Taihe style had become an accustomed style of writers. Its content was characterized by emotion revealing and humanized features

\section{TAIHE POETRY UNDER THE INFLUENCE OF REGIONAL CULTURE}

The History of the North - Wenyuan Zhuanxu described Taihe literature and said: "In the years of Taihe, Emperor Xiaowen loved literature very much, was level-pegging with Emperor Wudi of Han Dynasty, and even surpassed Cao Pi. His temperament was elegant and profound. He could write good poems and prose, and men of letters admired and appreciated the new writing style. It has new rhythm and tune, and the scale of tune changed accordingly. With few sources of words, it has more true feelings, moistens the old style and creates new style, which is unprecedented. Therefore, it is elegant and remarkable writing, and conforms to standard. The literary style follows the technique of antithesis. After many years many literati have not heard of anything unique" $"$. It describes the general characteristics of poetry in the Taihe period. Under the influence of Confucianism, prose and poems also changed in the period. The poems of Northern Wei Dynasty, edited in Poetry of Pre-Qin, Han, Wei and Northern and Southern Dynasties ${ }^{12}$ by Lu Qinli are of different contents. Some describes scenery and some sing antiquity. The emotional styles are also different, and some are generous and some are grievous. But the general style is simple and plain, which is the general characteristic of Taihe poetry.

\section{Joint Speaking in the Bamboo Pavilion of Fangzhang} Xuanhu:

In Mianshui, Emperor Gaozu and his officials stayed in the bamboo pavilion of Fangzhang Xuanhu, and Dao Zhao and Zheng Yi were also there. They entertained themselves by drinking spirit and writing poems. Emperor Gaozu said: "with the sun shining the earth, there is a shade in the left corner of the river". Pengcheng Wang Xie said: "under the cover of your keen intelligence and excellent judgment, the country is peaceful and prosperous". Zheng Yi said: "the thunder split the gate of heaven, and we could see the heaven far away". Xing Luan said: "Emperor Shun wielded an axe and wielded power. We cannot but think of his virtue". Dao Zhao said: "the words of emperor could determine the destiny of the nation". Emperor Gaozu said: "I was happy to hear your advice, and keep the general mood of society bright". Song Bian said: "the political reform of Wenwang benefit Jiangzhao, and his contribution was eulogized everywhere". Emperor Gaozu said to Dao Zhao: "I was not successful in dealing with national affairs, so I often gather officials to help me. These views were good, and please record it, Xing Luan. On that year, his official Pin Ding got sick heavily. Every time I heard this, I was sad"13.

In the poetry creation of Emperor Xiaowen, it reflects Emperor Xiaowen Loved poetry, and often exchange views with his officials. It also is a reflection of a mutual happiness between the emperor and his officials and a reflection of Confucianism thought of "poetry could be harmonious". The antithesis in the poem reflects Emperor Xiaowen's strength and determination to propose literature. Literature is placed under the realm of aesthetic contemplation and becomes the embodiment of elegant life.

In addition, Wang $\mathrm{Su}, \mathrm{Zu}$ Ying and Yuan Xie also left one poems respectively in the Taihe period. Other literati, such as Liu Chang, Pengcheng Wang Yuancheng, Xing Luan, Cheng Lingqiu, had not left any works. Wang Su's Sadness for Pengcheng, Zu Ying's Sadness for Pengcheng and Yuan Xie's Pine Poet of Tongdi Mount upon Emperor's Order are generous and simple in characteristic style. These poems

11 (Northern Qi) Wei Shou, Wui Shu - Biography of Wen Yuan, China Book Bureau, 1974, Page 1870.

12 Lu Qinli, Editor. Poetry of Pre-Qin, Han, Wei, Jin and Southern and Northern Dynasties, China Book Bureau, 2006, Page 2006.

13 Lu Qinli, Editor. Poetry of Pre-Qin, Han, Wei, Jin and Southern and Northern Dynasties, China Book Bureau, 2006, Page 2200. 
described the hard and cold scenery of the north snow and singed general and sad history event, leaving a general and sad feelings for readers.

In the Northern Wei Dynasty the poetry creation under the influence of Taihe literary style has changed from the previous generation, paying attention to the reflection of the realistic politics and caring for the inner world. The social functions of the poetry in the Confucian thought have been embodied in the poetry of Taihe style. Poetry paid more attention to inner and emotional expression than prose writing, so the creation of poetry in this period is not as rich as prose, but it has also developed. The exchange of regional culture and the influence of Confucianism made the Northern Wei Dynasty and the whole northern literature gradually developed and changed, providing a model for the development of later literature.

\section{CONCLUSION}

The development of literature in the Northern Wei Dynasty was represented by Taihe literary style, which is a progress of northern literature in the Northern and Southern Dynasties. Confucianism and the literary style of the Southern Dynasties gradually influenced the progress and development of literature in the northern region in a form of regional cultural exchange. And Confucianism was also increasingly infiltrated into the rule of the northern regime, and Confucianism gradually tended to be institutionalized, promoting and consolidating the position of the scholars in the Northern Dynasties, and the scholars began to enter the regime of the Northern Dynasties' minority regimes, participating in political affairs and speaking directly. At the same time, Confucianism, as academic thought, has been paid great attention to, and it has become a cultural value infiltrating into the development of the Northern Wei literature, promoting the blend of the north and the South style of literature and promoting the development of the Northern literature.

\section{REFERENCES}

[1] (Warring States Period) Noted by Meng Ke, Yang Bojun and Yang Fengbin. Mencius. Changsha: Yuelu Book Society, 2000. (战国)孟辑著; 杨伯峻,杨逢涁注译.孟子[M].长沙:岳麓书社,2000.

[2] (North Qi) Wei Shou. Wei Shu. Beijing: China Book Bureau, 1974. (北 齐)魏收.魏书[M].北京:中华书局, 1974 .

[3] (Tang) Wei Zheng et al. Sui Shu. Beijing: China Book Bureau, 1974. (唐)魏徵等.隋书[M].北京:中华书局, 1974 .

[4] (Qing) Yan Kejun, Editor. Articles of Ancient Three Dynasties, Qin, Han, Three Kingdoms and Six Dynasties. Beijing: China Book Bureau, 1958. (清)严可均校辑.全上古三代秦汉三国六朝文[M].北京:中华书 局, 1958 .

[5] Lu Qinli, Editor. Poetry of Pre-Qin, Han, Wei, Jin, Northern and Southern Dynasties. Beijing: Zhonghua Book Bureau, 2006. 逯钦立辑 校.先秦汉魏晋南北朝诗[M]. 北京:中华书局,2006. 